defects from the literary point of view, the book is to be welcomed as an addition to the scanty literature of glass from the pen of a practical glass worker, and it will no doubt find many appreciative readers among those interested in decorative glass. W, R.

\section{ASTRONOMY, MYTH, AND LEGEND.}

The Judgment of Paris, and some other Legends Astronomically Considered. By the Hon. Emmeline M. Plunket. Pp. iv+ I99; illustrated. (London : J. Murray, I908.) Price $7 s$. 6d. net.

NO archæologist denies that in the "myth-making age" (whenever that may have been; we are still making myths now) our primitive ancestors were often struck with the appearance of the heavenly bodies, and made pretty stories out of them. But what he does deny is that, at any rate in the case of Greece, the majority of the myths, or anything like the majority, are of celestial origin. We know, also, far too much about the probable early history of the Egean countries to believe for a moment that many Greek legends (as distinct from myths) are connected with the movements of the sun, moon, and stars. But the Hon. Miss Plunket finds an astronomical explanation for all legends as well as myths. She confuses the two; for her Achilles or, Agamemnon are as unreal as Aphrodite and Hera, and all four are but symbols, so to speak, of some aspect of the heavenly bodies at some time or other.

To the Greeks Aphrodite and Hera were as real as Achilles or Agamemnon. Miss Plunket reverses the process. Both she and the Greeks are equally uncritical in their method! For her everything is unreal and astronomical. But why should not some of the myths, and a few of the legends, be astronomical, and the rest not? After all, we are not all of us star-gazing now, and there is no proof that our " myth-making" ancestors were more given to the pursuit than we are. An archæological discovery has shown us that many of these astronomical explanations of legend are mere fantasy, as we fear much of Mișs Plunket's book is. There is far more earthy reality about these stories than she thinks. The murder of Agamemnon by Klytaimnestra and Aigisthos, in which Miss Plunket sees " mythically chronicled an eclipse occurring at or close to the season of the winter solstice," would be considered by the modern archæological historian to be a legendary reminiscence of a real tragedy of a particularly ghastly character perpetrated in the royal burg of Mycenæ at some time during the period of Achaian domination, no more. Why should it be anything else? Why be astronomical? Why should the Greeks have woven all these cryptic legends about stars?

To regard the Trojan war, too, as an astronomical myth after the discoveries of Schliemann is to exhibit a peculiar point of view. Miss Plunket calls it a "conviction." "Convictions" are unscientific; they are merely inverted prejudices, and no scientific worker has any business to be dominated by them. We note, however, from many indications, that Miss Plunket would be scientific enough could she but conceive the possibility that every myth and legend is not necessarily of astronomical origin. With her suggestion that the Gorgon's head is originally the cold full moon we are in cordial agreement. We have then in the Perseus story a queer folk-tale of a sort of Jack-the-Giant-Killer who went up into the sky and brought the moon down, as the primitive mind, like the child-mind now, could easily conceive the wonderful person as doing. In this there is nothing astronomical; and the Medusa on the shield of Athene may very well be the full moon on the body of the goddess of the grey-blue night-sky, $\gamma \lambda a v \kappa \omega \hat{\omega} \iota s^{\prime} \mathrm{A} \theta \theta^{\prime} \nu \eta$; why not? But there is no astronomical complication here, only a general sky-goddess with the moon on her, as it naturally would be.

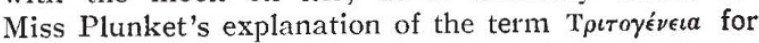
Athene as "born of 'Trita," a deity of the Avesta, is at least more probable than the very doubtful con. nection with Lake Tritonis in Libya. The author makes other suggestions which will compel the most sceptical critic to read her work with attention and respect, even though he may differ toto caelo from its main contentions.

H. R. Hall.

\section{HEAT FOR ENGINEERS.}

Heat for Engineers. A Treatise on Heat, with Special Regard to its Practical Applications. By Chas. R. Darling. Pp. xii +430 . (London : E. and F. Spon, Ltd., 1908.) Price I2s. 6a. net.

A NY author who attempts to cover the syllabus A outlined in the preface and contents of this treatise needs considerably more than $4 \mathrm{r} 5$ pages of the ordinary-size text-book in which to do that properly. Too much has been attempted, and a great opportunity has not been made use of to the fullest advantage. Some portions of the book are elementary to a degree which irritates; other portions are so advanced that needful and useful sections have been sacrificed in order to keep the size of the book within the usual limits. Clearly the author should have divided his matter into two volumes, one elementary and the other advanced. In the preface there is rightly expressed the opinion that "the numerous applications of heat in modern industrial processes" . . . do not "receive more than the briefest mention in ordinary treatises on heat," and it is the avowed object of this book to remedy that omission. Yet "Practical Heat Engines" are disposed of in sixteen pages, and one searches in vain for a mention of that most interesting and instructive heat motorthe Diesel engine. There is nothing about evaporators; a study of the action of multiple-effect evaporators especially conveys much that is useful to the engineering student. We obtain the impression that the book is meant for the student in physics, and not for the engineer. If that is conceded, then there is more reason for its contents. In any case, however, space might have been found for dealing with the errors of the aneroid barometer, since the instrument itself is considered and described. An improvement in the arrangement of the contents

$$
\text { NO. 2047, VOL. 79] }
$$

